
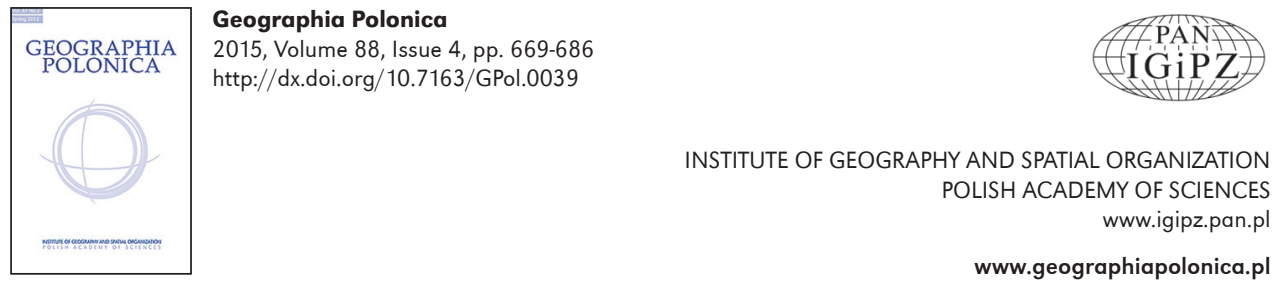

\title{
'JOHN-PAUL-THE-SECOND-ISATION' OF CULTURAL LANDSCAPE IN POLAND
}

\section{Lucyna Przybylska ${ }^{1}$ - Izabela Sołjan ${ }^{2}$}

\author{
${ }^{1}$ Institute of Geography \\ University of Gdańsk \\ Bażyńskiego 4, 80-309 Gdańsk: Poland \\ e-mail: geolp@ug.edu.pl \\ ${ }^{2}$ Institute of Geography and Spatial Management \\ Jagiellonian University \\ Gronostajowa 7, 30-387 Kraków: Poland \\ e-mail: izabela.soljan@uj.edu.pl
}

\begin{abstract}
The aim of this paper is to identify, categorize, explain and interpret the process of 'John-Paul-the-Secondisation' which has been taking place for the last three decades in Poland. 'John-Paul-the-Second-isation' is perceived as a kind of landscape sacralisation, i.e. the process of filling the cultural landscape with objects and phenomena related to Pope John Paul II, his work and personality. The process is analysed on three basic levels: architectural, nominative and temporal. The growing cult of the 'Polish Pope' is a visible sign of social, cultural, religious and political factors influencing cultural landscape.
\end{abstract}

\section{Key words}

cultural landscape - John Paul II - Poland • geography of religion • sacralisation

\section{Introduction}

Since 1978, when Karol Wojtyła was elected the pope and assumed the name John Paul II, Poland and some other Catholic countries have been facing the increasing interest in his personality, which developed into a kind of 'cult' over the years of his pontificate (1978-2005). Streets, squares and different institutions have been renamed. Monu- ments and plaques dedicated to the Pope have been put up. For instance, before John Paul II died (2 April 2005) there had been 8 papal monuments in Italy, 3 or more in Spain, 5 in Portugal, 25 in Latin America, over 30 in the USA and over 10 in Canada (Ożóg 2007). Interestingly, the abovementioned initiatives had been undertaken long before the Church officially acknowledged the cult of John Paul II (beatification in 2011, 
canonisation in 2014). In Poland the process of cultural landscape conversion triggered by the cult of the Pope is more visible than in other countries and it has accelerated since 2005, when the pope passed away.

This paper fits into the contemporary research trend of various scientific disciplines on public manifestations of religiosity in modern societies. Among American geographers who deal with the presence of religion in landscape there are: Park (1994), Stump (2008) and Zelinsky (2010); among the Asian ones - Kong (2010) and Matsui (2013). In Europe religious issues are examined by i. a. Knippenberg (1998), Henkel (2005), Grčić (2011), Matlovič (2011), Havlicek \& Hupkova (2013), and in Poland by Jackowski et al. (2009), Klima (2011), Bilska-Wodecka (2012), Przybylska (2014). Religious phenomena in landscape are also of interest to sociologists, architects, historians and other researchers (Ostwalt 2003; Nelson 2006; Jenkins 2007; Pixten \& Dikomitis 2012; Davie 2013).

There are numerous academic papers on Pope John Paul II. In foreign literature authors mainly focus on selected aspects of the pontificate of John Paul II, in particular on the role of the Pope in the life of the Catholic Church in the world and in Poland (Williams 1982; Cava 1992; Guth 1995; Sutton 1997; Burrows 2006; Udomah 2014), in the abolition of the communist system (Zagacki 2001), in the development of interreligious dialogue (Sherwin \& Kasimow 2005; Dalin \& Levering 2008) and on his widely understood political and social activity (Williams 1982; Coughlin 2003; Sisk 2007). Few Polish scholars drew attention to the rise of various papal memorials in space (Jagosz 2000; Ożóg 2007; Klekot 2007; Czepczyński 2008). It appears that there have been no comprehensive studies of papal objects, names and events in Poland to date, except for the book on sacralisation of public spaces in Poland (Przybylska 2014); this paper quotes some of these findings as well as develops further going analysis.
The research is based on both quantitative and qualitative measures including cartographic presentation of the phenomenon. This study employs the method of analysis and criticism of written texts, of the investigation of documents and individual cases, and of observation. It must be emphasized that the vast majority of relevant literature and source documents (also available on Internet) is Polish or written in English by Polish scholars.

In this paper, cultural landscape is conceived in a symbolic way as "a site of emblematic representation, a constructed space, comprising elements that play a pivotal role in the construction, mobilization, and representation of identity" (Whelan 2010: 61). Landscape elements (set of social relations and practices) act as spatializations of memory; the projection of identity onto physical territory. According to Czepczyński (2008: 15) cultural landscape can be "a synthesis of history and space, of memories and places, connotations and material forms, always changing and re-contexted". To conclude, this paper is an example of cultural landscape research in the semantic approach, which is an extremely opposite to another major direction of landscape research - a physiogeographical approach called landscape ecology (Myga-Piątek 2012).

The authors refer to the term 'John-Paulthe-Second-isation' applied by Czepczyński (2008: 168) in his book on cultural landscape of post-socialist cities. Czepczyński (2008) drew attention to growing cult of the 'Polish Pope' in Poland since the early 1990s, which manifests itself through naming various places after the Pope and celebrating his death anniversary. However, Czepczyński did not perform any spatial or quantitative analysis of this phenomenon, treating it as one of many examples of new landscape symbols in Eastern Europe. The authors of this paper are of the opinion that the term 'John-Paul-the-Second-isation' can be defined as a kind of landscape sacralisation, i.e. the process of filling the cultural landscape with objects and phenomena referring to Pope 
John Paul II: his personality and work. In the paper the process is analysed on three basic levels: architectural, nominative, and temporal. While architectural sacralisation refers mainly to churches and monuments, nominative sacralisation is represented by schools, cities, streets and other buildings under the patronage of the Pope, and temporal sacralisation in turn involves rituals held in public spaces. What is more, two of them seem to be polar opposites, since architectural elements lead to the emergence of stable religious landscapes, while temporal events taking place in public spaces can be described as examples of immaterial ephemeral landscapes. Finally, the nominative sacralisation is assumed to be somewhere in between. For instance, the name of a patron placed on a street plaque is a material sign of the immaterial world communicating by means of languages.

Furthermore, the process of 'John-Paulthe-Second-isation' can be perceived as a visible sign of the return of religion to public spaces. Different kinds of manifestation of religion in landscape prove that religion is increasing in significance in many parts of the world contrary to generally assumed, until the early 1990s, the secularization process of modernized societies (Ostwalt 2003; Jenkins 2007; Davie 2013). Considering the case of Poland, we must not forget about the political determinant of the landscape sacralisation - the Great Transformation in 1989 which initiated all contemporary socio-spatial changes. Studies conducted in different parts of Poland in recent years prove that it is a process that occurs in the whole country, not limited to one province or small municipal units; 'John-Paul-the-Second-isation' is part of it (Przybylska 2014).

The purpose of the article is to identify, categorize, explain and interpret the ongoing process of 'John-Paul-the-Second-isation'. When it was possible (due to data available) the authors emphasize the spatial differentiation of the process. This study is a contribution to that subdiscipline of cultural geography which is the geography of religion. It may be interesting for researchers of other countries and continents where such a process of landscape sacralisation does not occur.

\section{Architectural sacralisation \\ Papal churches}

The objects of religious cult, in particular churches and chapels, are examples of the most significant and conspicuous elements of the architectural sacralisation of landscape. At present there are 33 Roman Catholic churches and chapels operating under the patronage of Saint John Paul II. Owing to a relatively short time of the official recognition of the cult of John Paul II, 14 churches which are to be dedicated to his person are still under construction (as of October 2014), and so far temporary chapels have been erected, where the services are held and the life of the parish is centered (Fig. 1).

The process of papal parishes and churches emergence started in principle in the year 2005 after the Pope's death. They were most frequently an expression of tribute to the deceased and often a way to commemorate his presence in a given locality or diocese. This phenomenon is interesting insofar as in a few cases, owing to the immediately opened process of beatification, parishes were not given dedication, but a name, e.g. Parafia Akademicka w Stalowej Woli (Academic Parish in Stalowa Wola) or Parafia na Równi Szaflarskiej in Nowy Targ (Równia Szaflarska Parish in Nowy Targ). In the case of the latter, on the very day of John Paul II's beatification, 1 May 2011, a decree by Kraków Cardinal Stanisław Dziwisz on dedicating the parish to Blessed John Paul II was read. In December 2014 the consecration ceremony of the church shall take place. Another practice involved a change of current dedication, which was effectuated, for example, in a parish in Lublin, established in 2010 and dedicated originally to Blessed Priest Jerzy Popiełuszko. As a result of the change, since 27 March 2012 it has been Blessed John Paul II Parish. Similar situations took place, i.a. in Bydgoszcz, Nowy Sacz and in Ełk. They 


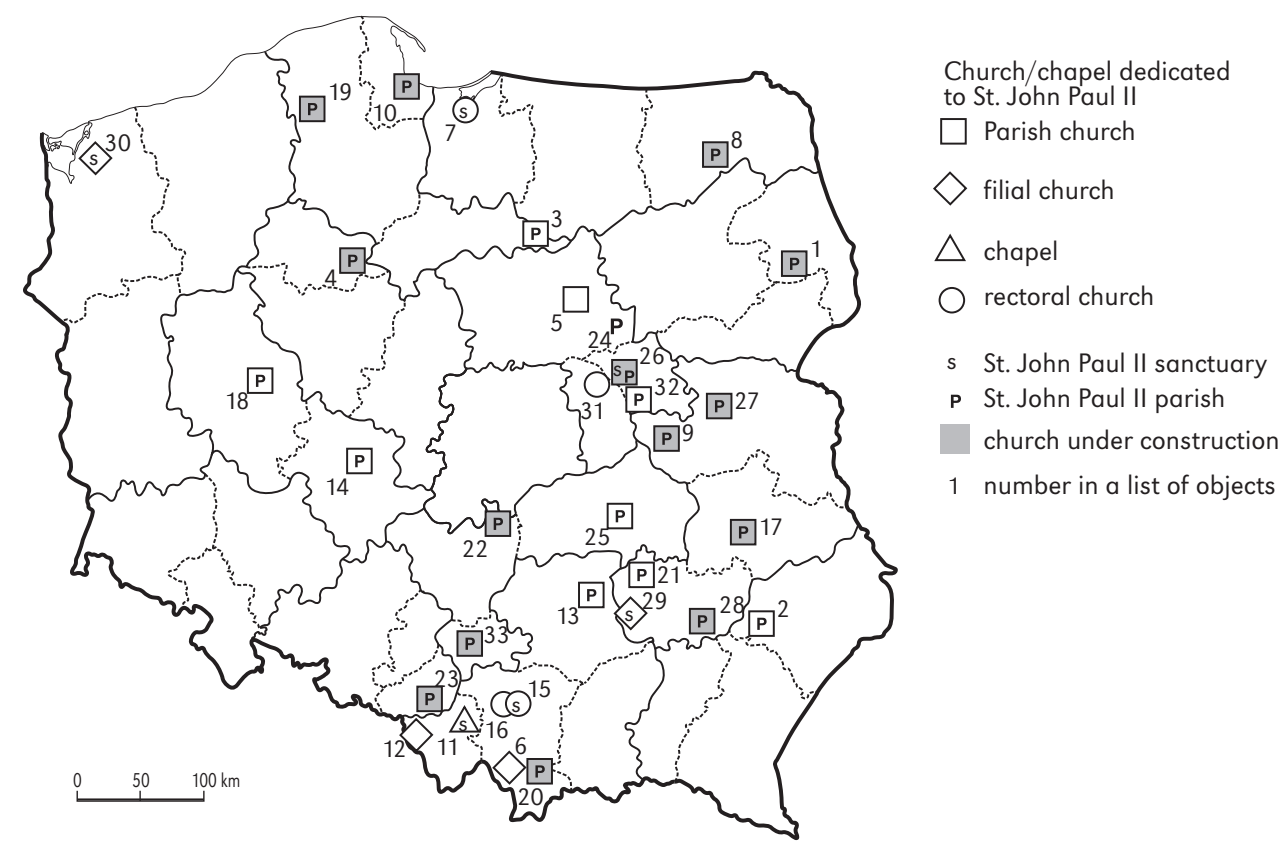

Figure 1. St. John Paul II churches and chapels in Poland as of 2014 by dioceses

List of objects (location) 1 - Białystok, 2 - Biłgoraj, 3 - Burkat, 4 - Bydgoszcz, 5 - Ciechanów, 6 - Długopole, 7 - Elblag, 8 - Ełk, 9 - Garwolin-Sulbiny, 10 - Gdańsk-Łostowice, 11 - Groń Jana Pawła II, 12 - Iłownica, 13 - Kaczyn, 14 - Kalisz, 15 - Kraków (Centrum Jana Pawła), 16 - Kraków-Ruczaj, 17 - Lublin, 18 - Luboń, 19 - Mądrzechowa, 20 - Nowy Targ, 21 - Ostrowiec Świętokrzyski, 22 - Piotrków Trybunalski, 23 - Pszczyna, 24 - Pultusk, 25 - Radom, 26 - Radzymin, 27 - Siedlce, 28 - Stalowa Wola, 29 - Staszów, 30 - Śniatowo, 31 Warszawa (Warsaw), 32 - Warszawa-Wesoła, 33 - Zawiercie.

involved most often newly established parishes, which in principle had temporary patrons appointed.

A church in Ciechanów (central Poland) and another in Śniatowo near Kamień Pomorski (northern Poland) were the first ones dedicated to Blessed John Paul II and they were consecrated in less than 20 days after his beatification. The structures had been completed much earlier, but their dedication was postponed until the beatification. Whereas the first church dedicated to the already Saint John Paul II was the one in Grajewo (northeastern Poland), consecrated three hours after the Pope had been declared saint. Few "papal" churches and chapels are located in rural areas (7) and in the western Poland. At present Archdiocese of Kraków, the region John Paul II was born, is a leader of Saint John Paul II churches (4).
Sanctuaries dedicated to John Paul II are special places of his cult (Fig 1). The pattern of their formation was similar to the one described above, since they had already been created before the official acknowledgement of the cult. Saint John Paul II sanctuary in Kraków is of the highest rank (Fig. 2). It constitutes an integral part of the big complex of sacral buildings which is under construction - Centrum Jana Pawła II (John Paul II Centre), located in the immediate vicinity of Sanktuarium Miłosierdzia Bożego w Łagiewnikach (Sanctuary of the Divine Mercy in Łagiewniki). The date of the solemn opening of the sanctuary, i.e. 11 June 2011, is assumed to mark the beginning of the cult of the Pope in this center. Another unique place is Sanktuarium Górskie na Groniu (Mountain Sanctuary on Groń Mountain Peak in the Low Beskids). It was established to commemorate hiking trips made by Karol 


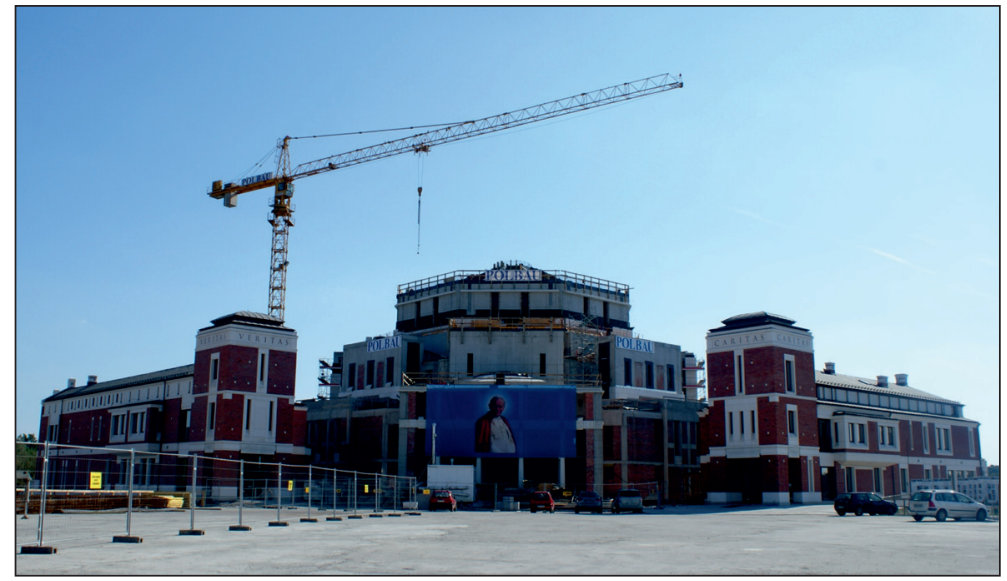

Figure 2. Saint John Paul II sanctuary in Kraków under construction (2014)

Wojtyła, who climbed the peak of Leskowiec and Jaworzyna on numerous occasions, when he was still a young man and later as a priest, bishop and cardinal. In 1981 Jaworzyna peak was renamed John Paul II Groń (Sanktuarium Górskie na Groniu Jana Pawła II 2014). Saint John Paul II sanctuaries have also been founded in Radzymin (central Poland), Staszów (south-eastern Poland), Śniatowo and Elbląg (northern Poland).

\section{Papal monuments}

The first Polish monument of John Paul II was erected in Kraków in 1980 and by April 2005 there were already not less than 230 of them (Ożóg 2007). Klima (2010) states that there are over 640 papal monuments in Poland. The source referred to in figure 3 is Orlicz (2008), a Polish Tourist and Sightseeing Society (PTTK) guide, who counted 471 monuments including 455 sculptures of different size and 16 plaques and obelisks. Such a great number of objects, almost half of which were raised still during the Pope's lifetime, is a phenomenon which does not lend itself to unambiguous interpretation. The mere idea of erecting monuments is very frequently criticized, suggesting other more appropriate forms of commemorating the great Pole. They are also frowned upon for their little or entirely missing aesthetic appeal.
The psychological or sociological phenomenon of monuments can be attributed to the feeling of pride that the Poles have in the great compatriot and the wish to accentuate the bond with him which is felt even by small local communities. Moreover, the monuments are physically present in public space, unlike, e.g. a foundation named after John Paul II, which therefore makes them a tangible proof of recognizing John Paul II as a prominent personality in the history of the Polish nation and society.

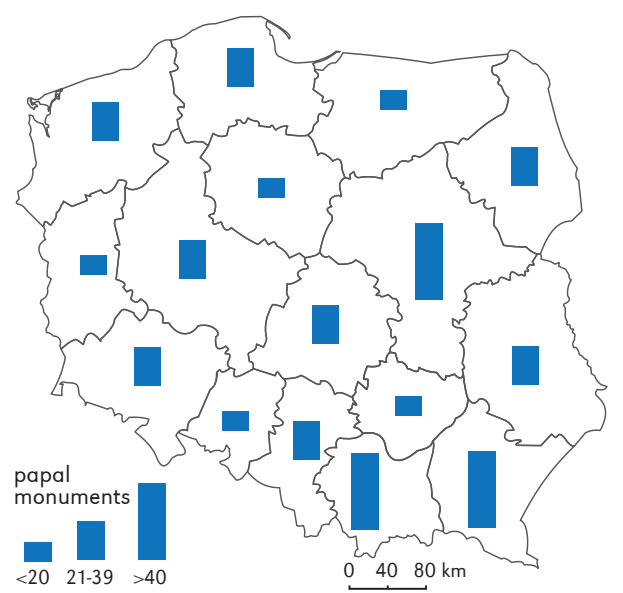

Figure 3. Monuments of John Paul II in Poland as of 2008, by voivodeships

Source: based on Orlicz (2008) 
There is some spatial regularity in the distribution of papal monuments. As it can be observed in figure 3 there are less (below 20) papal monuments in southern and western provinces (called voivodeships) and a lot more (over 40) can be found in south-eastern Poland and in Mazowieckie Voivodeship. It is clearly evident that Małopolskie Voivodeship is a leader having 71 such monuments. The society in the province where John Paul II was born (Wadowice), studied (Kraków) and went on trips (the Carpathian Mountains) was somehow 'forced' to commemorate him.

It should be emphasized that papal monuments and plaques are placed in prestigious places. For example, there is a plaque, mounted in 2011 to commemorate the beatification of John Paul II, located in front of the entrance to a new park with an observation tower in the village of Gniewino, neighboring a huge water power station in Żarnowiec in northern Poland (Fig. 4).

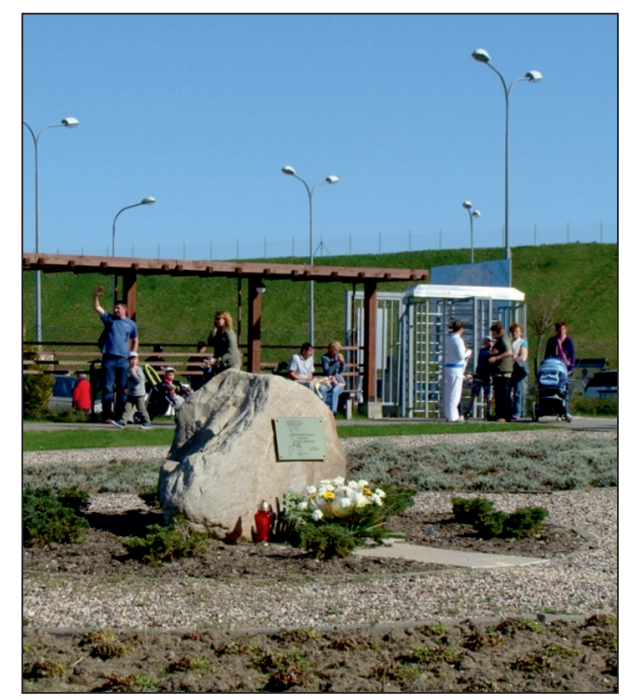

Figure 4. The plaque commemorating John Paul II in Gniewino (2012, photo by Lucyna Przybylska)

The map by Orlicz (2008) allows for determining the location type of papal monuments. It must be emphasized that the majority of papal monuments in Poland (72\%) are located next to sacral objects, usually a parish church or a monastery. When considering their location in other spaces (28\%), among the most popular objects there are public schools under the patronage of John Paul II, then marketplaces and finally squares.

A question emerges: Are papal monuments more popular in cities or in the countryside? Because John Paul II used to go to the mountains before he would leave for Rome, nowadays there are also many memorials to those visits even in the protected areas. Analyzing the sacredness in six national parks in Polish Carpathian Mountains Ptaszycka-Jackowska (2005) noticed that objects and rituals commemorating pope John Paul II became common as early as in the 1980s. According to Orlicz (2008) it can be estimated that among 132 monuments erected in public spaces $65 \%$ have been located in urban areas. Thus, it proves that both urban and rural areas have experienced the same level of intensification of the process of architectural 'John-Paul-the-Second-isation', as the urbanization rate in Poland is 61.4\% (CSO 2011b). In any case, the highest (13.8 m tall) papal statue in the world was erected in April 2013 in the city of Częstochowa in a private miniature park of sacred sites reproductions.

Papal monuments and plaques are usually put up as joint enterprises resulting from the cooperation of residents, local authorities and a rich founder. For instance, the monument in Sopot was founded by a Polish emigrant to the USA and the one in Nowy Sacz by local businessmen. Unveiling a John Paul II monument is always a meaningful event for local residents engaging leaders and authorities of a city, town or village, which is well documented on municipal websites. For example, the monument placed in the marketplace in Nowy Sacz (southern Poland), which was officially opened on 16th October 2005, the so called 'Papal Day', on the 27th anniversary of the election of Polish Cardinal Karol Wojtyła as Pope John Paul II (Nowy Sacz 2012), was unveiled by the local president, the chairman of the town council and one of the owners of an ice factory - the founders of the monument. The statute of the Pope was also blessed by the bishop. In Nowy Sacz 
there is also a Papal Fountain, which was opened on the 1st anniversary of the death of the Pope (2nd April 2006), and a boulder called the "Peter's Rock" placed in a park on 16th June 2005, on the 6th anniversary of the papal visit to Sadecki Land. It should be noted, however, that Nowy Sacz is not the only town in Poland with several architectural objects devoted to John Paul II.

\section{Papal museums}

Cultural landscape based on the heritage of John Paul II is also created by museums and memorial halls. The most important and at the same time the most attractive object is undoubtedly John Paul II Family Home Museum (Muzeum Dom Rodzinny Jana Pawła II) in Wadowice. The fact that it has been arranged in the tenement house where Karol Wojtyła's family lived is a great asset of the museum. In the house the original interior layout with the Wojtyła family's apartment on the first floor has been preserved. The museum was opened in 1984, yet in the beginning the exhibition was much more modest in scope than it is at present. In 2006 the Ryszard Krauze Foundation bought the whole building from the owners' descendant and donated it to Archdiocese of Kraków. Currently, it is a very modern multimedia museum with numerous themes devoted to the Pope (Muzeum Dom Rodzinny Jana Pawła /I 2014). Other establishments have been created i.a. in John Paul II Centre in Kraków (Centrum Jana Pawła II w Krakowie), in Archdiocesan Museum in Przemyśl (Muzeum Archidiecezjalne w Przemyślu) and in Diocesan John Paul II Pilgrimage Centre in Stary Sacz (Diecezjalne Centrum Pielgrzymowania). Smaller exhibitions also have a museumlike character, e.g. the one in the sanctuary in Kalwaria Zebrzydowska, in Dukla or in the first parish of Karol as parish priest in Niegowić. The museum of John Paul II and the Primate Wyszyński (Muzeum Jana Pawła II i Prymasa Wyszyńskiego) at the Temple of Divine Providence (Świątynia Opatrzności Bożej) in Warsaw is currently under construc- tion. Sometimes the wish to create a museum proves stronger than real capabilities of the promoters. For example, there was an initiative to open a John Paul II museum in Zawoja and yet due to a limited amount of exhibits the idea was not put into effect. Memorial halls are often established in schools and in other facilities under the patronage of the Pope, i.a. such a Memorial Hall was created in a nursery school in Iwonicz-Zdrój. Finally, one should not forget about John Paul II Mobile Museum (virtually an $18 \mathrm{~m}$ long vehicle painted in colors of the Vatican flag), which exhibits commemorative Pope items, promotes his teaching all over Poland and collects money for the abovementioned sanctuary of John Paul II in Kraków. Because of its mobile character it seems to be also an example of (described further) temporal sacralisation.

\section{Nominative sacralisation Papal schools}

The course of 'John-Paul-the-Second-isation' process of Polish cultural landscape also involves naming of some different types of public institutions and places. Educational institutions named after the Polish Pope, mostly public schools of different types, illustrate the process of nominative sacralisation taking place in Poland.

The history of the non-governmental organization "Rodzina szkół noszących imię Jana Pawła II" (The family of schools named after John Paul II) started in 1998, on 16th October, the 20th anniversary of John Paul II's pontificate, when there was a ceremony of naming the public Primary School no 41 in Radom (RSJP 2012). The event inspired one of the parents having children in this school to seek other schools having the same patron. The idea was supported by the school headmaster, the diocesan curia and the Superintendent of Schools Office (Kuratorium Oświaty). Their first Poland-wide meeting was held in November 1998 in Radom and it was attended by 20 representatives of 15 papal schools. 
The phenomenon of John Paul II school patronage is diversified both in time and space. The first such educational institutions were established in the early 1990 s, and there were already 50 of them in the mid-1990s (RSJP 2012). Then this number increased rapidly to 250 in the millennium year. And four years later there were already 500 papal schools. However, the largest development was observed in 2005 and 2006, since in the year that Pope died and in the year that followed the amount of papal schools increased to nearly 1000. In the next few years the process of development of papal schools network was rather stable and in 2010 the network comprised 1150 educational institutions.

A kind of 'geography of papal patrocinium' emerges when analyzing the database of papal schools (RSJP 2012). Similarly to the abovementioned characteristics of papal monuments distribution, the same three regions also proved to be the leaders in this case. Namely, there are over 150 papal schools in Małopolskie and Mazowieckie Voivodeships and 127 in Podkarpackie. While western regions distinguish themselves by the smallest amount of such schools (below 35). Out of over 10 types of educational units bearing the name of John Paul II only $3 \%$ account for non-public schools and over $90 \%$ for a part of the compulsory education system in Poland: 6-year primary schools and 3-year lower secondary schools called 'gimnazjum'. On average John Paul II is the patron of $6.1 \%$ Polish public primary schools and lower secondary schools (Fig. 5).

Considering the relative figures, the group of voivodeships with higher rates (above 7\%) includes two south-eastern regions and additionally one in the north-east and one in the south-west of Poland. Two southern voivodeships, along with a north-western one have less than $5 \%$ of papal schools. Therefore, it is clear that the network of papal schools is more developed in the south than in the north. Moreover, taking into account smaller diocesan units Kraków diocese proves to be an indisputable leader.

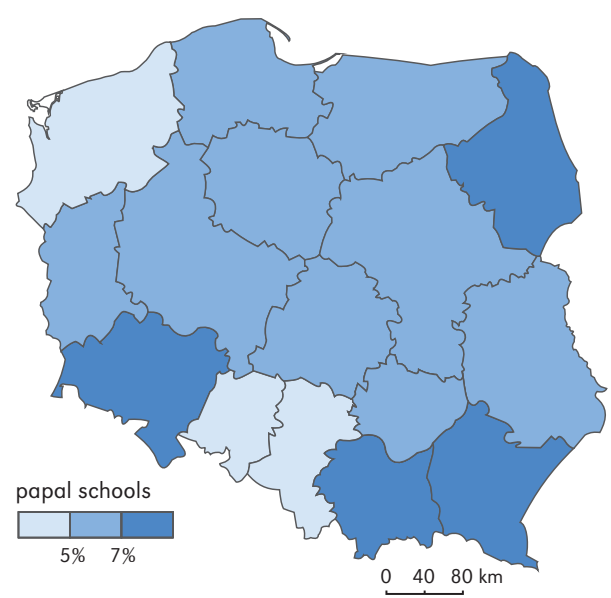

Figure 5. Primary and lower secondary schools dedicated to John Paul II in Poland as of 2012, by voivodeships (except for special schools)

Source: based on RSJP (2012) and CSO (2011a)

\section{Papal Routes}

According to Jackowski (2003) a cultural tourist differs from a religious one with respect to motivation. Among 348 contemporary cultural routes (of international, interregional, regional or local range) in Poland as many as 71 have something in common with religion, which proves if not the rise of religious tourism, then the return of institutional forms of religious culture into public spaces. So called Papal Routes are a part of regional or local cultural routes (Gaweł 2012).

Since 1979 a spontaneous activity leading to mark places and routes visited by Karol Wojtyła as a young priest, later as a bishop, and finally as a Pope, has become a fast developing enterprise in Poland. In 2004 it led to the establishment of the Papal Routes Foundation, which cooperates with the Church having its own guardian, because the Papal Routes are "the idea promoting his teaching and style of recreation" (Własiuk 2010: 328). However, there are also some initiatives undertaken by local authorities in order to mark places connected to the Pope, e. g. Karol Wojtyła's Trail in Wadowice opened in 1999 and a city tourist route "In 
the footsteps of John Paul II" opened in 2002 in Kraków.

Most Papal Routes cover mountainous areas located in southern Poland. The Papal Routes Foundation uses existing tourist trails delineated by the Polish Tourist and Sightseeing Society (PTTK) or it creates new ones marking them with a sign of a yellow cross on a triangle base. Sometimes there are boards erected along such routes informing about the Pope and that particular place. It must be emphasized that Małopolskie Voivodeship has the largest number of the Papal Routes in Poland. Although papal foot trails prevail in Poland, other forms of recreation have also been developed. Northern regions, for instance, are known for the initiatives to commemorate the time when Karol Wojtyła was canoeing in the Lakelands. A good example of such enterprise is the Papal Canoeing Trail along the Słupia River opened in 2009. One can also find some papal biking routes. A 250-km cycle trail of Dolnośląskie Papal Routes in south-western Poland is the longest one.

\section{Others}

'John-Paul-the-Second-isation' is well visible in other kinds of municipal naming, especially streets. The group of religious street names varies from $1.8 \%$ to $5.3 \%$ in 18 voivodeship capitals in Poland (Przybylska 2014). John Paul II streets are present in every provincial (voivodeship) capital and in 6 out of them they appear even twice (e.g. there is John Paul II Street and John Paul II Square in Katowice). Other popes are not so popular, as there is only one street dedicated to Pope John XXIII in Kraków and one to Pope Paul VI in Szczecin. It must be emphasized that streets and squares named after John Paul II are usually located in city centers. There are also marketplaces bearing the name of the Pope, like in Morag and Wabrzeźno. The other examples include main and/or prestigious streets, e.g. the longest alley (over $4 \mathrm{~km}$ long) in Kraków and alleys in Toruń, Gdynia and Warsaw.
Nominative 'John-Paul-the-Second-isation' also involves adding the name to the official names of facilities such as: universities (John Paul II Catholic University of Lublin, the Pontifical University of John Paul II in Kraków), a famous wooden pier in Sopot, a 1-km long bridge in Puławy, Kraków-Balice International Airport, a train running on KrakówWadowice route, a hotel in Wrocław, and numerous hospitals and parks. In Pomorskie Voivodeship the papal name has been given to an observation tower on the highest peak of the region called Wieżyca (329 m above sea level). Moreover, John Paul II has been made "the honored citizen" in over 100 cities. There was even a strong need to make the shipyard in Gdansk, previously named after Lenin, dedicated to the Polish Pope, but the Bishop of Gdansk Archdiocese dissuaded the public opinion from that idea.

\section{Temporal sacralisation}

\section{Meetings and masses}

Solemn masses followed by the Pope's ceremonial rides were unprecedented openair mass events sacralizing public space in Poland in the period of 1979-2002. It should be noted that the Pope visited the southern part of Poland during each of his 8 pilgrimages to the beloved homeland $(1979,1983$, 1987, 1991, 1995, 1997, 1999 and 2002). In 1987 there were also some northern cities on the tour and in 1991 and 1997 some north-eastern cities and a Baltic city of Koszalin (in 1991). Kraków was the city that the Holy Father visited most frequently and, accordingly, the services held there were attended by the highest number of people (2 M in 1979, $1.5 \mathrm{M}$ in $1983,1.5 \mathrm{M}$ in 1987 and $2.5 \mathrm{M}$ in 2002 (Serwis Papieski 2013).

The capital of Poland also witnessed several mass meetings. In 1983 there were $1.5 \mathrm{M}$ pilgrims in Warsaw. The most famous speech was delivered by the Pope at Victory Square during the time of the People's Republic of Poland in June 1979. Over 500 thousand people heard the historic sentence: "Let your Spirit descend and renew the face of the 
earth. This earth!" These words encouraged the beginning of deconstruction of the communist system in Poland in the following decade. Twenty years later, in June 1999 at this place, now called Piłsudski Square, John Paul Il again celebrated mass but this time in an already free Poland.

\section{Papal Days}

John Paul II is commemorated in Poland at least twice a year. Since 2001 there has been a nationwide celebration held on the Sunday preceding October 16th, the date of the election of the Polish cardinal Karol Wojtyła as Pope John Paul II. The first Papal Day was celebrated in 6 cities: Kraków, Szczecin, Radom, Poznań, Lublin and Zakopane. The second one was celebrated in every diocese, so in two years the Papal Day gained a Poland-wide range. It has also been exported abroad to Australia, the USA, Canada, Great Britain, France and Germany, however its character has been rather local there.

The event runs in four dimensions: intellectual, spiritual, artistic and charitable. The idea of Papal Days emerged after John Paul II's pilgrimage to Poland in 1999. In the year that followed Fundacja Dzieło Nowego Tysiąclecia (New Millennium Work Foundation) was established to promote Pope's teaching through cultural and social practices and events. On the eve of the Papal Day at the Royal Castle in Warsaw the Foundation hands one of the most prestigious awards in the Catholic Church (TOTUS awards). The concert in the Castle Square in Warsaw has always been the culmination of the Papal Day celebration (FDNT 2013). The Day of John Paul II is accompanied by other art events, both local and nationwide, undertaken by parishes and local governments. Prayers in public spaces are also a part of these initiatives.

There have been media campaigns conducted since 2006 to promote Papal Days. For instance, from 17 September to 14 October 2007 there were 200 billboards and 300 citylights put up in public spaces in large cities. There were also advertisements placed in the means of public transport in 28 cities and as the Foundation claims these adds were exempt from usual charges (FDNT 2013).

Another kind of temporal 'John-Paulthe-Second-isation' takes place in spring. Although the biggest collection of candles, flowers, flags, pictures and prayers written on small pieces of paper was displayed at the beginning of April 2005 (Fig. 6), yet the anniversary of his death on 2nd April is still celebrated in that way in main squares in almost every Polish city or town.

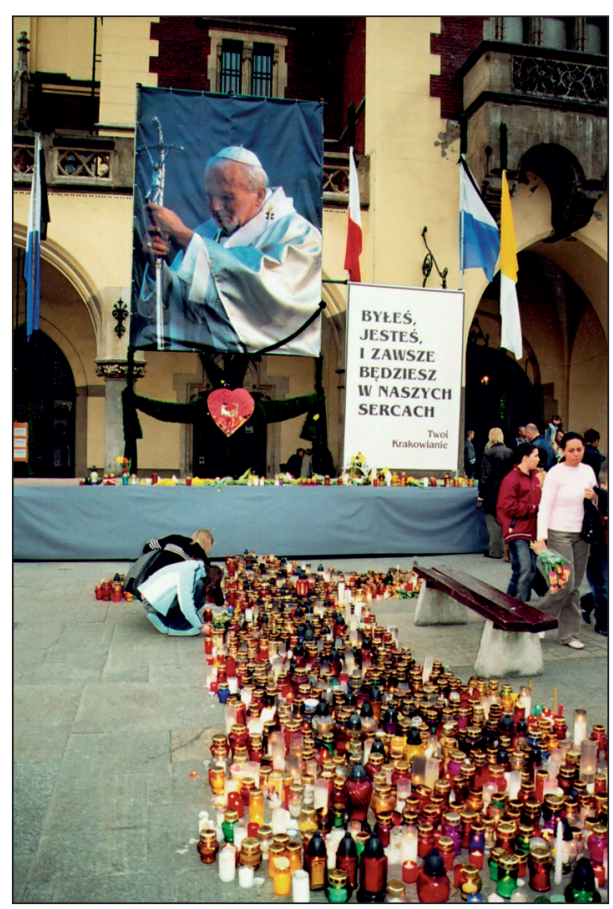

Figure 6 . The memorable day of Pope's death in Kraków (2005, photo by Izabela Sołjan)

On 2 April some cities witness processions and prayers which often end at 21:37 - at the exact time when the Pope died. Such an event took place, e.g. in 2010, when the Way of the Cross commemorating the death of John Paul II proceeded from the Castle Square in Warsaw to the cross erected in memorable Marshal Józef Piłsudski Square. Among other unique events happening during the Papal Days there is the Way of the Cross procession, 
which has been held in the Bieszczady mountains since 2006. On 2 April 2011 about 130 people climbed its final station, i.e. Tarnica, the highest peak, $1246 \mathrm{~m}$ above the sea level.

Initiatives undertaken in 2014 to celebrate the canonisation of John Paul II on 27 April 2014 also fall within the definition of the Papal Days. The offer of papal cruises by Krakowska Żegluga Pasażerska (2014) is a spectacular example of such activity. In the year of the Pope's canonisation during the trips on the Vistula River the tourists could take advantage of a special offer and listen to fragments of speeches and homilies by the Pope, which were made available in a multimedia form. In the years to come it is quite possible that the celebration of the canonisation day of the end of April will become another day to be celebrated along the abovementioned "papal anniversaries", i.e. 16 October and 2 April, which are events already embedded in the calendars of many cities and villages. And yet, it can also happen that people and institutions engaged in the celebration of the papal days will opt for one of these dates.

\section{Papal runs}

Papal Runs are also an expression of the nationwide temporal form of 'John-Paul-theSecond-isation'. They have been an active way of commemorating the beloved Pope by Polish sportsmen and sportswomen since the beginning of the 21st century. Apart from the name (Papal Runs), there are some other elements accompanying these sports events which give them a unique character among examples of ephemeral landscape sacralisation. To begin with, there are posters with a portrait of John Paul II, which make people willing to take part in the Papal Runs. Secondly, common prayers are sometimes held before or after such events. Moreover, some participants run with the Polish national flags and papal flags, e.g. during relay races around Poland called the 'April Runs', which have been organized since the second half of the first decade of the 21st century. Some street runs commemorating John Paul II are part of the Papal Day celebrations, like the one held in Kartuzy (northern Poland). Others, in turn, are meaningful gmina events (gmina - an administrative unit in Poland) having a half-sports and half-religious character, e.g. the street run in Karlino (north-western Poland). In the years 2000-2010 groups of 90-324 competitors from Poland and even from Ukraine, Belarus, Germany, Russia, Kenya and Tanzania took part in the latter one. The run in Karlino, like the ones in many other localities, starts and finishes next to a sacral object. In this case, it is at the largest Polish statue of the Blessed Virgin Mary in the village of Domacyno. Another run held in Piekary Ślaskie (southern Poland) finishes at the papal monument. In 2012 the best runners of 6th Piekary John Paul II Street Run were awarded statues of beatified Pope John Paul II.

\section{Discussion}

Religious landscapes reflect diversity, negotiation and usually mirror religious hegemony (Everett 2002). The process of 'John-Paulthe-Second-isation' is a visible sign of Christian identity of Polish society. Due to border changes and the destruction of Polish Jews, Poland was left with a 95 per cent Roman Catholic population, with small Greek Catholic, Orthodox, Protestant, Jewish and Muslim minorities (Herbert 2001). This nearly homogeneous society has begun to develop its own cultural landscape despite the fact that for over 40 years the internal policy of the communist state affected religious life.

Contemporary architectural, nominative and temporal commemoration of John Pau II epitomize continuation of the old tradition of expressing religion to the world outside which is, nota bene, interpreted differently, for instance, as the right to evangelize, and/or as a demonstration of symbolic power. Besides the homogeneous denominational character of a very religious society, specific political conditions seem to be the most important 
reasons for the proliferation of religious structures in Polish landscape, including the forms related to Pope John Paul II.

Religiosity is measured for instance by church attendance rate (called dominicantes rate). In 1980 51\% of Poles and in $201140 \%$ of them went to Roman Catholic churches every Sunday. It is worth noting that in the period 1980-2011 in 4 neighboring south eastern dioceses, including the Cracovian one, the rate reached highest values varying from $66 \%$ to $75 \%$ in 1980 and from 52\% to $68 \%$ in 2011 (ISKK 2013).

The abovementioned 'specific political conditions' have been a reference point for many researchers investigating religion in Poland (Casanova 1994; Herbert 2001; Klima 2011; Rykała 2011; Bilska-Wodecka 2012). Some of them have concluded that the Polish Catholic Church has played an important role in the Polish national identity throughout history. Three factors may account for this historical role, as Herbert (2001: 39) writes: "the disappearance of the Polish state, leaving the Catholic Church (and the Polish language) as central repositories of national identity throughout the nineteenth century, the continued denial of Polish independence under Soviet domination, and the virtual monopoly of the Roman Catholic Church on Polish religious life since 1945". Similarly Casanova (1994) claims that Church-nation identification occurred between 1795 and 1914 when the Roman Catholic Church was the only institution capable of infiltrating three Participants' borders.

It is assumed that the public space sacralisation (and landscape sacralisation) develops under two main conditions: the need to express faith on the one hand and the possibility to do it on the other (Przybylska 2014). The first one is an internal factor depending on above-mentioned religiosity, while the second one is related to external factors such as environment, politics, economy and social life. The Great Transformation which took place in 1989 in Poland and in the neighboring countries allowed for greater expression of social and religious needs in public.
Materialization of any ideas, not excluding those relating to John Paul II, is an important factor making young generation familiar with them and forming their identity. In the case of Poland 'John-Paul-the-Second-isation' exemplifies not only the expression of Christian identity, but also of the national one. It is a form of pride of the great Pole, who is famous globally for his religious, social and political role in the world at the turn of the centuries. His pastoral visits to 129 countries on 6 continents made him additionally very popular even in remote places. For this reason, plaques and monuments are encountered not only in Poland as it has already been mentioned in the introduction. Nevertheless, it is his dearest homeland - Poland that has been filled with papal memorials to the highest extent. In the case of Saint John Paul II patriotic and religious motives are highly interrelated in Poland.

The authors of the article are of the opinion that the phenomenon of 'John-Paul-theSecond-isation' has yet deeper grounds. While in no way diminishing the accomplishments of John Paul II and his role in the life of the Church and Polish nation, one cannot help but notice the process of myth creation making a national hero out of him. The image of John Paul II promoted by Polish media is the one of a man of Providence for Poland, the universal church, Europe and even for the whole world. John Paul II is the best Pole, the most saintly among the saints and the greatest pope, which manifests itself even in the appellation John Paul II the Great, not accorded to any other pope in the 20th century. The trend is also reflected in the changes of parish dedications, for example, as it has already been mentioned in the article - the change from Blessed Priest Jerzy Popiełuszko, or Father Pio to the dedication to John Paul II. Whereby an alarming situation arises, in which saints or the highest Church dignitaries undergo evaluation. This phenomenon is also manifested in the process of public space sacralisation in various dimensions; monuments of John Paul II spring up and numerous places and facilities are 
named after him. Consequently, the cult becomes banalized, since the image of John Paul II is reproduced not only on the objects of religious cult or monuments, but also on everyday articles, like e.g. dishes. To halt this process, one would have to focus more on spreading the teachings of John Paul II and promoting the values that he cherished most, instead of concentrating on uncritical highlighting of his uniqueness and greatness. The current process of John-Paul-the-Secondisation of the territory of Poland undoubtedly indicates that the Pope is widely acclaimed by Poles as an exceptional compatriot who will go down in the world history. However, launching yet another new initiative devoted to the Pope may produce an effect, unintended by its initiators, of crossing a certain boundary and transforming the cult of John Paul II into megalomania.

As it was presented, partly on maps (Figs. 1, 3 and 5), the spatial distribution of manifestations of the landscape sacralisation process related to John Paul II is more noticeable in south-eastern Poland. A kind of national pride felt by the residents of Małopolskie Voivodeship with the capital in Kraków has probably contributed to such a result. After all, it is the province where future Pope was raised, educated and where he taught and served as priest and bishop. A large number of papal monuments, schools and papal routes in this region can also be linked with higher than average religiosity in the south-eastern part of the country which resulted from historical processes. Ożóg (2007) combines density of papal monuments with political borders established before 1914. The highest density in the south-eastern regions is observed in the former Austrian territory dominated by the Catholics, the medium one in the north-eastern area, i.e. in the former Russian territory where the Orthodox prevailed and the lowest one in the western part of contemporary Poland, previously populated mainly by Protestants - German Empire.

Freedom of speech and other democratic rights took the place of the principles of the communist regime in 1989. Since that moment the Polish people have again had an opportunity to undertake enterprises which were previously hampered or forbidden. Erecting patriotic and religious monuments belong to the most spectacular Poland-wide processes of making up for the lost time, thus sometimes it is called the monument-mania. For example, there are lots of new monuments of Marshal Piłsudski - the Polish leader from the interwar period, memorials to the victims of communism and to the ones murdered in Siberia and Katyń. It should also be emphasized that the former street patrons and statues have been replaced with new 'proper heroes' including John Paul II. However, there is some inconsistency in this process, since names associated with socialism, commonly met in Poland, have been literally replaced, whereas socialist statues - mainly removed. For instance, in 1990 aleja Rewolucji Październikowej (October Revolution Alley) in Warsaw was converted to aleja Prymasa Tysiąclecia (The Primate of the Millennium Alley). In contrast, socialist monuments have simply been removed, as in the case of Feliks Dzierżyński statue in Warsaw and Lenin statue in Kraków. What is more, contemporary monuments do not exactly replace Lenin's or Stalin's personality cult, as there were few of them in Poland in the years when the socialist system reigned. An explosion in the number of new monuments has definitely outreached the process of replacing old memorials by new ones.

Furthermore, it can be stated that 'JohnPaul-the-Second-isation' reflects contemporary trends in Polish religious culture. Firstly, papal monuments are part of sacred architecture, described as traditional and sometimes recognized as having a low artistic value or even as being kitsch (Czepczyński 2008). Secondly, the highest papal monument in Częstochowa and Saint John Paul II Sanctuary in Kraków well represent a monumental trend in sacred architecture. In the 'Solidarity years' of 1980-1981 and after the end of the communism era a lot 
of monumental crosses were erected all over Poland. And yet, Sanctuary of Our Lady of Lichen (central Poland), completed in 2004, the largest one in Poland and the eighth largest in the world, as well as the 33-metre tall Christ the King Statue in Świebodzin (western Poland), opened in 2010, are the most famous examples of contemporary monumentalism.

What is more, papal memorials are the evidence that the symbol of the cross is very important to the Poles and it constitutes a distinctive feature of Polish cultural landscape. Statues of John Paul II are often accompanied with his pastoral cross or the cross itself is an element of the monument's construction, as in Gorzów Wielkopolski in western Poland (Fig. 7).

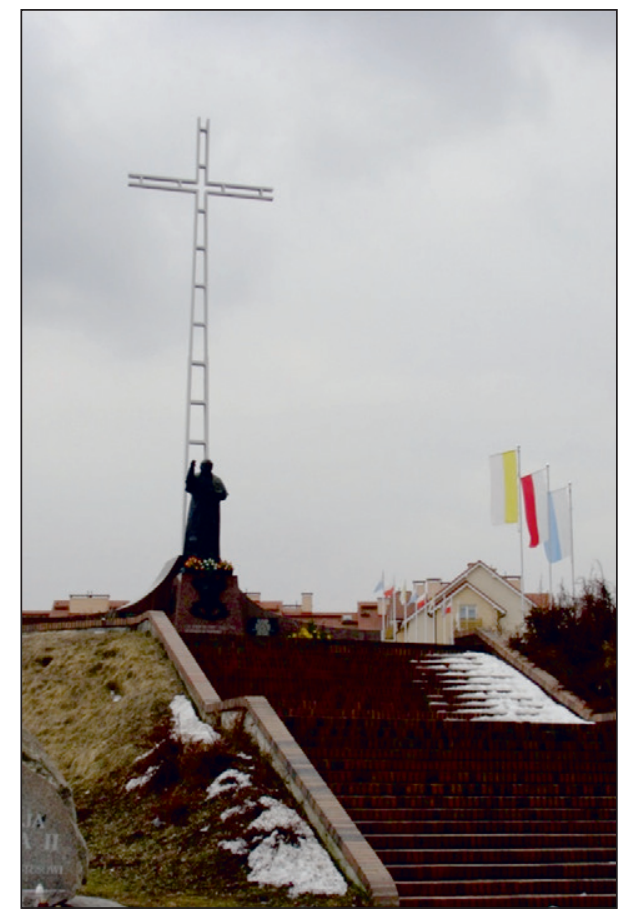

Figure 7. The statue of John Paul II in Gorzów Wielkopolski (2013, photo by Lucyna Przybylska)

Some forms of 'John-Paul-the-Second-isation' reflect other changes in Polish culture, yet modified in a subtle way, like for example, popularization of flags. McDonald's fast food restaurants and foreign-capital petrol stations were the leaders of 'flag-isation' in postcommunist Poland. Since the turn of the centuries more and more Vatican's yellow-white and Marian white-blue flags have been flown (Fig. 6 and Fig. 7).

Papal routes in turn are an example of official popularization of a new form of pilgrimaging, if not of individualisation of religious activities. In the 1970s and 1980s foot pilgrimages were mass and organized. They were perceived by citizens of towns and villages which they marched through as a rather loud event. In contrast, papal tourist routes, which have exploded lately or, e.g. the network of St. James Ways, which has been developed over the recent years, promote quite a different form of contact with the sacred: in silence, closer to nature, in privacy or in a small group. Speaking of pilgrim routes, it is worth quoting the opinion of Jackowski (2007), an outstanding Polish geographer of religion, who believes that developing religious tourism (to sanctuaries) is a chance for Poland. Can 'John-Paul-theSecond-isation', as well as the other types of sacralisation of Polish cultural landscape be perceived as something unique deserving of international promotion?

The celebrations of Papal Days in October described above seem to have something in common with the idea of festivalisation. Festivals offer to their spectators a variety of celebration forms and possibilities, but they also serve other functions, such as animating and dramatizing the world around them (Ronström 2011; Kuligowski 2013). As it has already been mentioned, Papal Days run in four dimensions: intellectual, spiritual, artistic and charitable. Concerts and TOTUS awards accompanying Papal Days in Warsaw match the idea of festivalisation of contemporary (and religious) culture.

Besides the individualisation and festivalisation of religious activities there has also been another trend well observed in Poland and all over the world for about 20-30 years. Petersson (2010) and Everett (2002) noticed a rise in spontaneous memorialisation 
referring to the placing of fresh flowers, lighted candles, religious symbols and photos at the sites of motor vehicle accidents and homicides. Temporal displays in places recalling John Paul II, as it was in the days of mourning in April 2005 (Fig. 6) and similar anniversary celebration rituals undoubtedly form part of contemporary memorial culture.

Finally, the phenomenon of 'John-Paul-theSecond-isation' can be treated as evidence that the matter of religion is an integral part of contemporary European society. Until the early 1990s secularization process of modernized societies was generally assumed (Davie 2013). From that time secularity of Europe began to be regarded as distinct and characteristic of this particular corner of the world. Davie (2013: 63), a British sociologist of religion, states that "the active religiosity in the United States, the massive shift to the South of global Christianity and the emergence of Islam as a major factor in the modern world order" made scholars coming out of the European context rethink their thesis. It is clear, as she stresses in the preface to the second edition of "Sociology of Religion. A Critical Agenda" that religion is gaining in significance in many parts of the world.

\section{Conclusions}

Because the phenomenon of 'John-Paul-theSecond-isation' is a very comprehensive one, it has been divided into three categories of landscape sacralisation: (1) architectural, (2) nominative and (3) temporal. As it was presented in the paper public manifestations of John Paul II's importance to Polish people vary in their forms including (1) churches, monuments, plaques and museums; (2) networks of tourist routes, cities which made John Paul II their honored citizen, dedication of streets, alleys, parks, squares, bridges, schools, hospitals and other objects and institutions to John Paul II; (3) crowds along streets and at open air services during papal pilgrimages to his homeland, numerous running races, celebrations of the anniversary of his election as Bishop of Rome, anniversary of his death, and the day of his canonisation. It must be emphasized that local authorities and Catholic authorities cooperate in the organization of these initiatives.

'John-Paul-the-Second-isation' is determined by a combination of different factors. The growing cult of the 'Polish Pope' is a visible sign of how social, cultural, religious and political factors influence cultural landscape conversion. Summing up, the authors find the cult of the 'Polish Pope' as:

1. A form of pride of the great Pole, famous all over the world.

2. A result of creating the image of John Paul II as national hero. When referring to myths of national heroes, a common occurrence in the history of Poland, in such a mode the figure of John Paul II may be interpreted as Man of Providence at the turn of the 21 st century. However, this direction, which is already making itself apparent in many circles in Poland, leads to distortion of the teachings and image of John Paul II, and thereby to banalization of the cult.

3. An example of new objects and phenomena in cultural landscape present all over the country, with a clear concentration in the south-east.

4. A reflection of contemporary trends in Polish culture, including religious culture (monumentalism, monument-mania, festivalisation, memorialisation, flag-isation, individualisation).

5. A sign of Christian identity of Polish society and an element of the hegemony of the Roman Catholic Church in post-communist Poland.

6. Evidence that the matter of religion is an integral part of contemporary European society (contrary to secularization thesis).

These conclusions can be verified in the future in Argentina. Will the Argentinians start erecting monuments and taking up other initiatives in memory of their compatriot Pope Francesco? 


\section{Acknowledgements}

This paper is part of a research project "Sacralisation of public spaces in Poland". It has been sponsored by the Polish National Science Centre pursuant to a decision DEC2011/03/B/HS1/00394.

\section{References}

BILSKA-WodeCKA E., 2012. Człowiek religijny i zwiqzki wyznaniowe $w$ przestrzeni miasta w XX i na poczatku XXI wieku. Kraków: Instytut Geografii i Gospodarki Przestrzennej UJ.

Burrows W.R., 2006. Mission and missiology in the pontificate of John Paul II. International Bulletin of Missionary Research, vol. 30, no. 1, pp. 3-8.

Casanova J., 1994. Public religions in the modern world. Chicago: Chicago University Press.

Cava R.D., 1992. Vatican policy. 1978-90: An updated overview. Social Research, vol. 59, no.1, pp. 169-199.

CoughuIn J.J., 2003. John Paul II and the dignity of the human being. Harvard Journal of Law and Public Policy, vol. 27, no. 1, pp. 65-79.

CSO, 2011a. Statistical Yearbook of the Regions - Poland. Warsaw: Central Statistical Office of Poland.

CSO, 2011b. Statistical Yearbook of the Republic of Poland. Warsaw: Central Statistical Office of Poland.

CZEPCZYŃSki M., 2008. Cultural landscape of postsocialist cities: Representation of powers and needs. Adlershot: Ashgate.

Dalin D.G., Levering M. (eds.), 2008. John Paul II and the Jewish people: A Jewish-Christian dialogue. Lanham, Maryland: Rowman \& Littlefield.

Davie G., 2013. Sociology of religion. A critical agenda. London: Sage.

EVERETT H., 2002. Roadside crosses in contemporary memorial culture. Denton: University of North Texas Press.

FNDT, 2013. Historia. Fundacja Dzieło Nowego Tysiąclecia, http://dzielo.pl/strona/3/historia [14 March 2015].
Editors' note:

Unless otherwise stated, the sources of tables and figures are the authors', on the basis of their own research.

GAWEt Ł., 2012. Szlaki dziedzictwa kulturowego. Teoria i praktyka zarzadzania. Kraków: Wydawnictwo Uniwersytetu Jagiellońskiego.

GRČlĆ M., 2011. Geografija religija. Belgrade: Faculty of Geography. University of Belgrade.

GutH K., 1996. Pilgrimages in contemporary Europe: Signs of national and universal culture. History of European Ideas, vol. 20, no. 4-6, pp. 831-835.

HavlíčEK T., Hupková M., 2013. Sacred structures in the landscape: The case of rural Czechia. Scottish Geographical Journal, vol. 129, no. 2, pp. 100-121.

Henkel R., 2005. Geography of religion - Rediscovering a subdiscipline. Hrvatsky Geografski Glasnik, vol. 67, no. 1, pp. 5-25.

Herbert D., 2001. Religion and the "Great Transformation" in Poland and East Germany [in:] D. Herbert (ed.), Religion and social transformations, Aldershot-Burlington-Singapore-Sydney: Ashgate, pp. 13-63.

ISKK, 2013. Church in Poland statistics. Instytut Statystyki Kościoła Katolickiego SAC, http://www. iskk.pl/kosciolnaswiecie.html [22 May 2013].

JACKOWSKI A., 2007. Pielgrzymki zagraniczne szansa dla rozwoju polskich ośrodków kultu religijnego. Prace Geograficzne, 117, Kraków: Instytut Geografii i Gospodarki Przestrzennej UJ, pp. 239-257.

Jackowski A., Sołjan I., Mróz F., 2009. Geografia pielgrzymek Jana Pawła II. Peregrinus Cracoviensis, no 20, pp. 19-47.

Jagosz M., 2000. Pomniki Jana Pawła // [in:] A. Dobroński, M. Kucharski (eds.), Papież Słowianin: Zwiastun nadziei, Toruń: Oficyna Wydawnicza Kucharski, pp. 297-326.

JenkINS P., 2007. The next Christendom: The coming of global Christianity. Oxford: Oxford University Press. 
KLIMA E., 2011. Przestrzeń religijna miasta. Łódź: Wydawnictwo Uniwersytetu Łódzkiego.

KNIPPENBERG H., 1998. Secularization in the Netherlands in its historical and geographical dimensions. GeoJournal, vol. 45, no. 3, pp. 209-220.

Kong L., 2010. Global shifts, theoretical shifts: Changing geographies of religion. Progress in Human Geography, vol. 34, no. 6, pp. 755-776.

Krakowska Żegluga Pasażerska, 2014. Rejsy papieskie, http://www.statekkrakow.com/tm/ 158-rejsy-papieskie.html [29 September 2014].

KULIgowskı W., 2013. Ludzie, sztuka, pieniadze: Festiwalizacja w Polsce. Czas Kultury, 175(4), pp. 4-15.

MATLOVIČ R., 2011. Geography of religion in Slovakia since 1990. Peregrinus Cracoviensis, 22, pp. 49-60.

MatsuI K., 2013. Geography of religion in Japan: Religious space, landscape, and behavior. Tokyo: Springer.

Muzeum Dom Rodzinny Jana PaWka II, 2014. http://domjp2.pl/, [2 September 2014].

Myga-PIĄteK U. 2012. Krajobrazy kulturowe: Aspekty ewolucyjne i typologiczne, Katowice: Uniwersytet Śląski.

Nelson Louis P. (ed.), 2006. American sanctuary: Understanding sacred spaces. Bloomington: Indiana University Press.

Nowy SACZ, 2012. Sadeckie pomniki, http://www. nowysacz.pl/pomniki-sdeckie [10 October 2015].

Orlicz R.H., 2008. Mapa pomników Jana Pawta II, http://www.msw-pttk.org.pl/odznaki/reg_ odznak/pjp2_mapa.html [12 October 2015].

Ostwald C., 2003. Secular steeples: Popular culture and the religious imagination. HarrisburgLondon-New York: Trinity Press International.

Ożóg K.S., 2007. Miedziany pielgrzym. Pomniki Jana Pawta II w Polsce w latach 1980-2005. Głogów: Państwowa Wyższa Szkoła Zawodowa.

Park C.C., 1994. Sacred worlds. An introduction to Geography and Religion. London-New York: Routledge.

Petersson A., 2010. The production of a memorial place: Materialising expressions of grief [in:] A. Maddrell, J. D. Sidaway (eds.), Deathscapes: Spaces for death, dying, mourning and remembrance, Farnham: Ashgate, pp. 141-159.
Pixten R., Dikomitis L. (eds), 2012. When God comes to town: Religious traditions in urban contexts. New York: Berghahn Books.

PRZYBYLSKA L., 2014. Sakralizacja przestrzeni publicznych w Polsce. Gdańsk: Wydawnictwo Uniwersytetu Gdańskiego.

PTAszyCKA-JACKOWSKA D., 2005. Sacrum w parkach narodowych w polskich Karpatach [in:] B. Domański, S. Skiba (eds.), Geografia i sacrum, vol. 2, Kraków: Instytut Geografii i Gospodarki Przestrzennej Uniwersytetu Jagiellońskiego, pp. 389-402.

Ronström O., 2011. Festivalisation: What a festival says - and does. Reflections over festivals and festivalisation. Paper read at the international colloquium "Sing a simple song", Neuchâtel, Switzerland, 15-16 September, 2011, http:// uu.diva-portal.org/smash/get/diva2:461099/ FULLTEXT01.pdf [30 May 2014].

RSJP, 2012. Rodzina szkół noszacych imię Jana Pawła II, http://rodzina.org.pl/baza-szkol/ [31 May 2015].

Rykata A., 2011. Mniejszości religijne w Polsce. Geneza, struktury przestrzenne, tło etniczne. Łódź: Wydawnictwo Uniwersytetu Łódzkiego.

Sanktuarium Górskie na Groniu Jana PawŁa II, 2014. http://www.gron.diecezja.bielsko.pl/ [22 September 2014].

Serwis PaPIESkI, 2013. Pielgrzymki Jana Pawła I/ do Polski. Wiara.pl, http://papiez.wiara.pl/Pielgrzymki_Jana_Pawla_II/Polskie [16 March 2015].

Sherwin B.L., Kasimow H., 2005. John Paul II and interreligious dialogue. Eugene: Wipf \& Stock Publishers.

SISK G.C., 2007. John Paul II: The quintessential religious witness in the public square. Journal of Catholic Legal Studies, vol. 45, no. 2, pp. 241-275.

Stump R.W., 2008. The Geography of religion: Faith, place and space. Lanham (Maryland): Rowman \& Littlefield Publishers.

Sutton M., 1997. John Paul II's idea of Europe. Religion, State and Society, vol. 25, no. 1, pp. 17-29.

Udomah J.M., 2014. The pontificate of John Paul II: A pastoral model for effective leadership. The Journal of Values-Based Leadership, vol. 7, no. 1, article 9 .

WhelanY Y., 2005. Mapping meanings in the cultural landscape [in:] G.J. Ashworth, B. Graham 
(eds.), Senses of place: Senses of time, Aldershot: Ashgate, pp. 61-71.

Williams G.H., 1982. John Paul II's concepts on church, state and society. Journal of Church and State, vol. 24, no. 3, pp. 463-496.

WŁasIUk U.J., 2010. Szlaki papieskie. Częstochowa: Edycja Świętego Pawła.

ZAGACKI K.S., 2001. Pope John Paul II and the crusade against communism: A case study in secu- lar and sacred time. Rhetoric \& Public Affairs, vol. 4, no. 4, pp. 689-710.

ZeLINSKY W., 2010. Organizing religious landscapes [in:] M.P. Conzen (ed.), The making of the American landscape, New York-London: Routledge, pp. 253-278. 